\title{
Geographical variation in spore morphology, gene sequences, and host specificity of Myxobolus arcticus (Myxozoa) infecting salmonid nerve tissues
}

\author{
Shigehiko Urawa', ${ }^{1,}$, Mark A. Freeman ${ }^{2}$, Stewart C. Johnson ${ }^{3}$, Simon R. M. Jones ${ }^{3}$, \\ Hiroshi Yokoyama ${ }^{4}$
}

\begin{abstract}
${ }^{1}$ Hokkaido National Fisheries Research Institute, Fisheries Research Agency, Toyohira-ku, Sapporo 062-0922, Japan ${ }^{2}$ Institute of Ocean and Earth Sciences \& Institute of Biological Sciences, University of Malaya, Kuala Lumpur 50603, Malaysia ${ }^{3}$ Department of Fisheries and Oceans, Pacific Biological Station, Nanaimo, British Columbia V9T 6N7, Canada ${ }^{4}$ Department of Aquatic Bioscience, Graduate School of Agricultural and Life Sciences, The University of Tokyo, Bunkyo, Tokyo 113-8657, Japan
\end{abstract}

\begin{abstract}
Myxobolus arcticus Pugachev and Khokhlov, 1979 is a freshwater myxosporean parasite infecting the nerve tissues of salmonid fishes throughout the Pacific region of Far East Asia and North America. The principal fish host is sockeye salmon Oncorhynchus nerka in North America and masu salmon $O$. masou in Japan. Actinospores of $M$. arcticus were isolated from the lumbriculid oligochaetes Lumbriculus variegatus and Stylodrilus heringianus in Japan and Canada, respectively. Morphological comparisons indicated that Japanese actinospores from $L$. variegatus have significantly shorter caudal projections than Canadian isolates from $S$. heringianus, whereas the corresponding myxospores are indistinguishable. Transmission experiments showed that sockeye salmon were rarely susceptible to the Japanese actinospores, while masu salmon are highly susceptible to this parasite. Sequences of 4560 base pairs of the ribosomal RNA (rRNA) gene, including small subunit (SSU) and internal transcribed spacer (ITS) regions, from Japanese and Canadian isolates had a high similarity over $99.9 \%$, suggesting that they may be conspecific. However, the biological data indicate that they are at least distinct strains. M. arcticus may be geographically isolated due to the specific homing migration of the anadromous fish hosts and has specialized its morphology and host selection for its local environment in the ongoing process of differentiation, potentially leading to speciation.
\end{abstract}

KEY WORDS: Myxobolus arcticus · Actinospore - Morphology · SSU rRNA · ITS rRNA · Susceptibility $\cdot$ Geographical variation $\cdot$ Salmonid

Resale or republication not permitted without written consent of the publisher

\section{INTRODUCTION}

Myxosporean parasites of fish with known life cycles, approximately $4 \%$ of species, have an alternate actinospore phase in annelids to fulfill the characteristic biphasic life cycles (Kent et al. 2001, Yokoyama 2003, Canning \& Okamura 2004). An exception of this is the marine myxosporean Enteromyxum leei, which can transmit directly among fish hosts (Diamant 1997). Thus, the taxonomy of myxosporeans should, when possible, also utilize the morphology of the actinospore stage as well as that of the corresponding myxospores that are traditionally used alone. Lom \& Dyková (2006) suggested that the specific identification of myxozoans also requires additional information such as molecular data, host and tissue tropisms, and geographical distribution.

Myxobolus arcticus Pugachev and Khokhlov, 1979 is a freshwater myxosporean infecting the central nerve tissues of salmonid fishes in the North Pacific 
coasts of Far East Asia and North America. The principal fish host is masu salmon Oncorhynchus masou in Japan (Awakura et al. 1995) and sockeye salmon O. nerka in Canada and Alaska (Bailey \& Margolis 1987, McDonald \& Margolis 1995, Moles \& Jensen 2000). The alternate invertebrate hosts are the aquatic oligochaetes Lumbriculus variegatus in Japan (Urawa \& Awakura 1994, Yokoyama \& Urawa 1997) and Stylodrilus heringianus in Canada (Kent et al. 1993), both classified in the family Lumbriculidae. $M$. arcticus has been used as a biological tag to identify the stock origins of salmon in open seas (Moles et al. 1990, Margolis 1998, Urawa et al. 1998) and has been associated with reduced swimming performance in host fish (Moles \& Heifetz 1998).

Various regions of the ribosomal RNA (rRNA) gene (small subunit [SSU], internal transcribed spacer [ITS] regions, and large subunit [LSU] are being increasingly utilized to study both inter- and intraspecific relationships of myxozoans (Fiala 2006, Whipps \& Kent 2006, Bartošová et al. 2009). Recently, variations of myxosporean spore morphology and SSU rDNA gene sequence were compared among Myxobolus species infecting salmonid nerve tissues (Urawa et al. 2009). The purpose of the present study was to determine the geographical variation in spore morphology and fish host susceptibility to the actinospore stage of $M$. arcticus in Japan and Canada. In addition, rRNA gene sequence data were used to demonstrate the genetic similarities between geographically distinct isolates of $M$. arcticus.

\section{MATERIALS AND METHODS}

\section{Spore collection}

Japanese actinospores of Myxobolus arcticus were collected from Lumbriculus variegatus from the Chitose River in Hokkaido $\left(42^{\circ} 48^{\prime} 29^{\prime \prime} \mathrm{N}\right.$, $\left.141^{\circ} 34^{\prime} 09^{\prime \prime} \mathrm{E}\right)$. Canadian actinospores were collected from Stylodrilus heringianus from Sproat Lake on southwest Vancouver Island, British Columbia $\left(49^{\circ} 17^{\prime} 25^{\prime \prime} \mathrm{N}, 124^{\circ} 55^{\prime} 10^{\prime \prime} \mathrm{W}\right)$. Collection of actinospores was in accordance with Yokoyama et al. (1991). Briefly, oligochaetes were individually placed in 48-well plates and kept at 8 to $9^{\circ} \mathrm{C}$ overnight. Actinospores released from the oligochaetes within $24 \mathrm{~h}$ were collected and used as described below. Mature myxospores of $M$. arcticus were collected from the medulla oblongata and spinal cord of masu salmon in the Chitose River and sockeye salmon in Sproat Lake.

\section{Spore observation}

Actinospores and myxospores ( $\mathrm{n}=30$ to 50 each) were fixed with $10 \%$ neutral buffered formalin and measured with an ocular micrometer under a compound microscope. Terminology used in the spore descriptions follows the guidelines of Lom \& Arthur (1989), Lom et al. (1997), and Lom \& Dyková (2006). The difference in measurements between Canadian and Japanese spores was tested by using a MannWhitney $U$-test, and $\mathrm{p}<0.05$ was set as the level of significance.

\section{Molecular analyses}

Myxospores and actinospores of Japanese and Canadian Myxobolus arcticus were collected as described above and stored frozen until required. All samples were taken in duplicate, from 2 fish and 2 oligochaetes, and all PCR reactions were performed in triplicate with DNA sequencing performed in both directions. DNA was extracted using a QIAamp DNA Mini Kit (Qiagen) following the manufacturer's tissue protocol and used as template DNA for PCR reactions. Small subunit ribosomal DNA (SSU rDNA) of the myxosporeans was amplified using a combination of previously described universal and specific primers (Freeman et al. 2008, Urawa et al. 2009). Partial LSU sequences were amplified from extracted actinospores, to minimize host DNA interference, using the primers NLF-184, NLR-1270, and NLR-1694 and PCR conditions described by van der Auwera et al. (1994) and Bartošová et al. (2009). From the initial LSU sequences obtained, a specific LSU reverse primer, Ma28-320r 5' TAC CAC CCA CTT CAG ACT GC 3', was used in combination with the semi-specific (binds to other nerve/cartilage-infecting Myxobolus spp.) SSU forward primer 18-1830f 5' ACA GGT CTG TGA TGC CCT AAG 3 ' to enable the amplification of the ITS regions. PCR conditions were $95^{\circ} \mathrm{C}$ for 4 min followed by 35 cycles of $94^{\circ} \mathrm{C}$ for $30 \mathrm{~s}, 55^{\circ} \mathrm{C}$ for $45 \mathrm{~s}, 72^{\circ} \mathrm{C}$ for $1 \mathrm{~min}$, with a final extension of $72^{\circ} \mathrm{C}$ for $7 \mathrm{~min}$. In addition, 2 further specific forward LSU primers (Ma28-310f 5' TGG GAA TGC AGT CTG AAG TG 3' and Ma28-1330f 5' ACT GCA AAC CGG TGA TAA CG 3') were used in combination with the reverse primers NLR-1270 and NLR-1694 to confirm and extend the initial LSU sequence reads.

The PCR products obtained were purified using a PCR purification kit (Qiagen), and the resulting DNA was used in direct sequencing reactions using BigDye $^{\mathrm{TM}}$ Terminator v3.1 chemistry and a 310 capil- 
lary DNA sequencer (Applied Biosystems). Contiguous sequences were constructed manually and compared to related Myxobolus spp. infecting salmonid nervous tissues, including isolates of $M$. arcticus from Canada (EU346378) and Japan (AB353130) using ClustalX (Thompson et al. 1997) and edited using the BioEdit sequence alignment editor (Hall 1999). Percentage divergence matrices were constructed in ClustalX using the neighbor-joining method (Saitou \& Nei 1987). Phylogenetic analyses were performed using maximum parsimony in PAUP $^{*} 4.0$ beta 10 using default settings and 1000 bootstrap replicates (Swofford 2002).

\section{In vitro assay of reaction of actinospores to fish mucus}

Skin mucus was collected from 6 species of healthy salmonid fish (masu salmon, sockeye salmon, chum salmon Oncorhynchus keta, pink salmon O. gorbuscha, rainbow trout O. mykiss, and brown trout Salmo trutta), and smeared onto a clean glass slide. Actinospore suspensions of Japanese Myxobolus arcticus were immediately added to the mucus and examined for release of sporoplasms by phasecontrast microscopy (Yokoyama et al. 1993). The reactivity of actinospores to fish mucus was determined on the basis of the sporoplasm release from at least 150 spores. An actinospore suspension without the addition of fish mucus served as a negative control.

\section{Transmission experiments}

To test the susceptibility of masu salmon to Japanese actinospores of Myxobolus arcticus, juvenile masu salmon were exposed to actinospores collected from Lumbriculus variegatus in the Chitose River for $1 \mathrm{~h}$ at concentrations of $0,10,100,200,500$, and 1000 spores fish ${ }^{-1}$. Juvenile chum, sockeye, pink, and amago salmon Oncorhynchus masou ishikawae, rainbow trout, and brown trout were also exposed to actinospores at concentrations of 200 to 1000 spores fish $^{-1}$ for $1 \mathrm{~h}$. These fish and unexposed control fish were transferred to $15 \mathrm{l}$ tanks, and reared with running well water at $10.5^{\circ} \mathrm{C}$. After $4 \mathrm{mo}$, the medulla oblongata was collected from each fish and smeared on a glass slide. These slides with cover slips were examined to confirm the presence of $M$. arcticus spores under a microscope at a magnification of $200 \times$.

\section{RESULTS}

\section{Morphological comparison}

Morphological characteristics of actinospores of Japanese Myxobolus arcticus were similar to those of Canadian $M$. arcticus in having an anchor-like triactinomyxon form with protruding tips of polar capsules and plasmodial sporoplasm. Japanese actinospores had significantly shorter caudal processes than Canadian ones, while there were no other considerable differences in morphometrics or in the number of sporozoites within the sporoplasm between the 2 actinospore isolates (Table 1, Fig. 1). The myxospores of the isolates from Canada and Japan were pyriform in valvular view and morphologically indistinguishable (Table 1).

\section{Molecular comparison}

SSU rDNA sequence data of 2025 nucleotide bases for each isolate determined in the present study
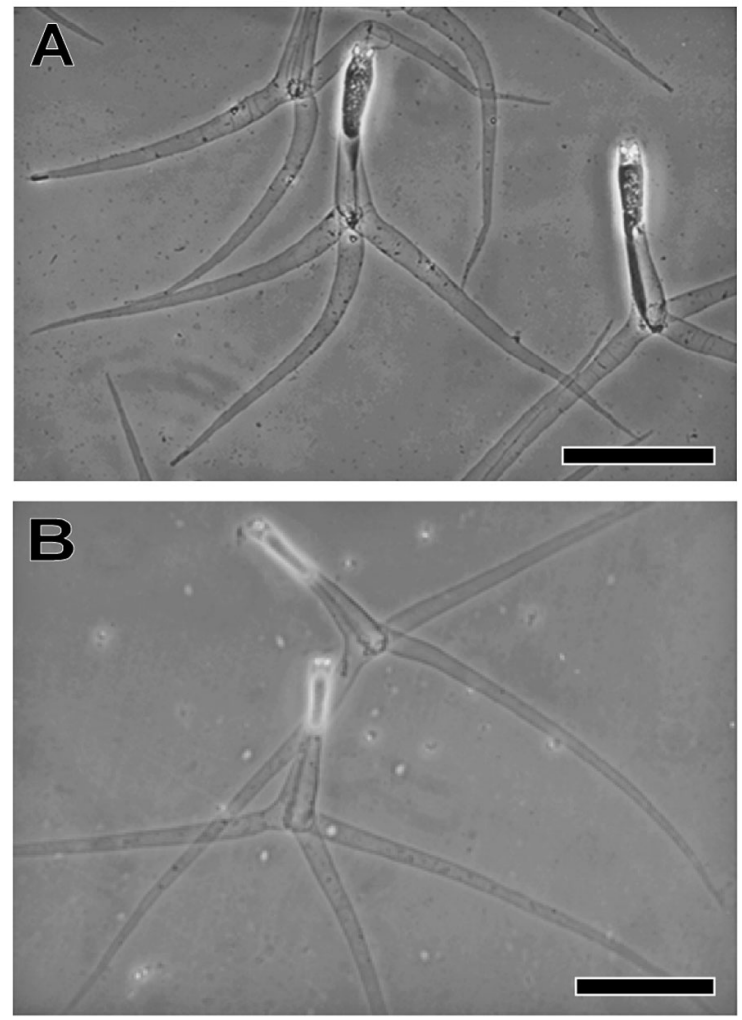

Fig. 1. Myxobolus arcticus. (A) Japanese actinospores released from Lumbriculus variegatus in the Chitose River, Hokkaido, and (B) Canadian actinospores from Stylodrilus heringianus in Sproat Lake on Vancouver Island, British Columbia. Scale bars $=0.1 \mathrm{~mm}$ 


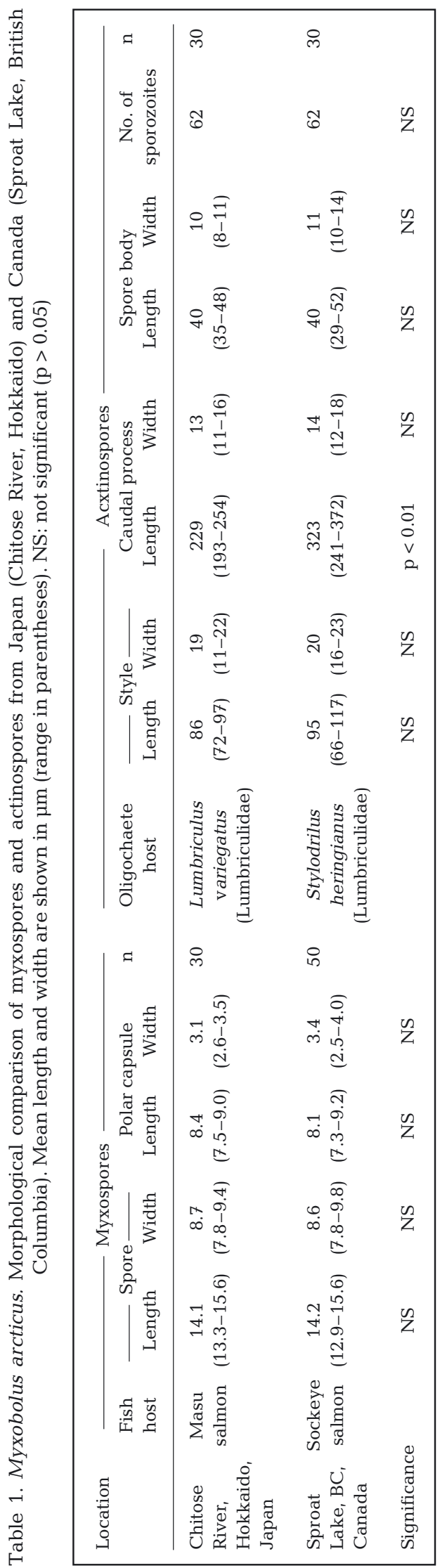

were deposited in GenBank: actinospores of Japanese Myxobolus arcticus (accession number AB353128) from Lumbriculus variegatus collected in the Chitose River; actinospores of Canadian M. arcticus (HQ113228) from Stylodrilus heringianus collected in Sproat Lake; and myxospores of Canadian M. arcticus (HQ113227) from sockeye salmon collected in Sproat Lake.

Partial SSU, complete ITS1, 5.8S, and ITS2, and partial LSU regions of the rRNA gene were successfully amplified and sequenced for actinospores and infected oligochaetes from both Japan and Canada, respectively. Sequences of $2754 \mathrm{bp}$ were generated for both isolates of Myxobolus arcticus and submitted to GenBank: actinospores of Japanese M. arcticus (JN003830) from Lumbriculus variegatus collected in the Chitose River and actinospores of Canadian $M$. arcticus (JN003829) from Stylodrilus heringianus collected in Sproat Lake.

The combined complete SSU, ITS1, 5.8S, ITS2, and partial LSU of the rRNA gene gave a total sequence read of $4560 \mathrm{bp}$ from both Japanese and Canadian isolates of Myxobolus arcticus.

\section{SSU rDNA}

The sequence from actinospores of Japanese Myxobolus arcticus (AB353128) is identical to the corresponding myxospore sequence from masu salmon (AB353130, Urawa et al. 2009). Likewise, the sequence data from Canadian actinospores (HQ113228) and myxospores (HQ113227) are identical. A single nucleotide base change is the only difference between the Japanese and Canadian isolates examined in this study, which gives an overall percentage similarity over $99.9 \%$, demonstrating a very high gene similarity (Table 2). Furthermore, another isolate of $M$. arcticus (EU346378, Ferguson et al. 2008) from British Columbia, Canada, has $100 \%$ identity to both the Japanese and Canadian isolates obtained in this study (Table 2), albeit over a shorter $(1130 \mathrm{bp})$ and more conserved part of the gene. In the phylogenetic analysis, all Japanese and Canadian isolates of $M$. arcticus form a robustly supported clade (Fig. 2).

\section{ITS regions and LSU rDNA}

The sequence from Japanese actinospores (JN003830) is over $99.9 \%$ similar to the sequence obtained from infected Canadian oligochaetes (JN003829). There are 
Table 2. Myxobolus spp. Percentage identities (above diagonal) of small subunit rDNA of selected species infecting salmonid neural tissues with the number of comparable bases used in the analyses (below diagonal)

\begin{tabular}{|c|c|c|c|c|c|c|c|c|c|c|}
\hline Species (host \& location) accession no. & 1 & 2 & 3 & 4 & 5 & 6 & 7 & 8 & 9 & 10 \\
\hline $\begin{array}{l}1 \text { M. arcticus (Lumbriculus variegatus, } \\
\text { Chitose River, Japan) }{ }^{\mathrm{a}} \text { AB353128 }\end{array}$ & & 100 & 100 & 99.95 & 99.95 & 97.05 & 97.01 & 95.78 & 93.85 & 93.54 \\
\hline $\begin{array}{l}2 \text { M. arcticus (Oncorhynchus masou, } \\
\text { Chitose River, Japan) AB353130 }\end{array}$ & 1970 & & 100 & 99.95 & 99.95 & 97.05 & 97.01 & 95.79 & 93.80 & 93.55 \\
\hline $\begin{array}{l}3 \text { M. arcticus (O. nerka, British Columbia, } \\
\text { Canada) EU346378 }\end{array}$ & 1128 & 1130 & & 100 & 100 & 96.81 & 97.26 & 95.4 & 93.88 & 93.62 \\
\hline $\begin{array}{l}4 \text { M. arcticus (O. nerka, Sproat Lake, } \\
\text { Canada) HQ113227 }\end{array}$ & 1970 & 1972 & 1130 & & 100 & 97.10 & 97.06 & 95.84 & 93.85 & 93.60 \\
\hline $\begin{array}{l}5 \text { M. arcticus (Stylodrilus heringianus, } \\
\text { Sproat Lake, Canada) }{ }^{\mathrm{a}} \text { HQ113228 }\end{array}$ & 1970 & 1972 & 1130 & 1972 & & 97.10 & 97.06 & 95.84 & 93.85 & 93.60 \\
\hline $\begin{array}{l}6 \text { M. kisutchi (O. kisutch, Washington, } \\
\text { USA) AB469988 }\end{array}$ & 1966 & 1968 & 1128 & 1968 & 1968 & & 97.00 & 95.53 & 93.59 & 93.65 \\
\hline $\begin{array}{l}7 \text { M. neurotropus (O. mykiss, Idaho, } \\
\text { USA) DQ846661 }\end{array}$ & 1970 & 1972 & 1130 & 1972 & 1972 & 1969 & & 95.84 & 93.96 & 93.96 \\
\hline $\begin{array}{l}8 \text { M. neurobius (Salmo trutta, Bergen, } \\
\text { Norway) AB469987 }\end{array}$ & 1969 & 1971 & 1130 & 1971 & 1971 & 1968 & 1972 & & 93.34 & 93.39 \\
\hline $\begin{array}{l}9 \text { M. murakamii (O. masou ishikawae, } \\
\text { Hiroshima, Japan) AB469984 }\end{array}$ & 1966 & 1968 & 1128 & 1968 & 1968 & 1967 & 1969 & 1968 & & 97.21 \\
\hline $\begin{array}{l}10 M . \text { fryeri }(O . \text { kisutch, Oregon, } \\
\text { USA) EU346370 }\end{array}$ & 1966 & 1968 & 1128 & 1968 & 1968 & 1967 & 1969 & 1968 & 1971 & \\
\hline
\end{tabular}

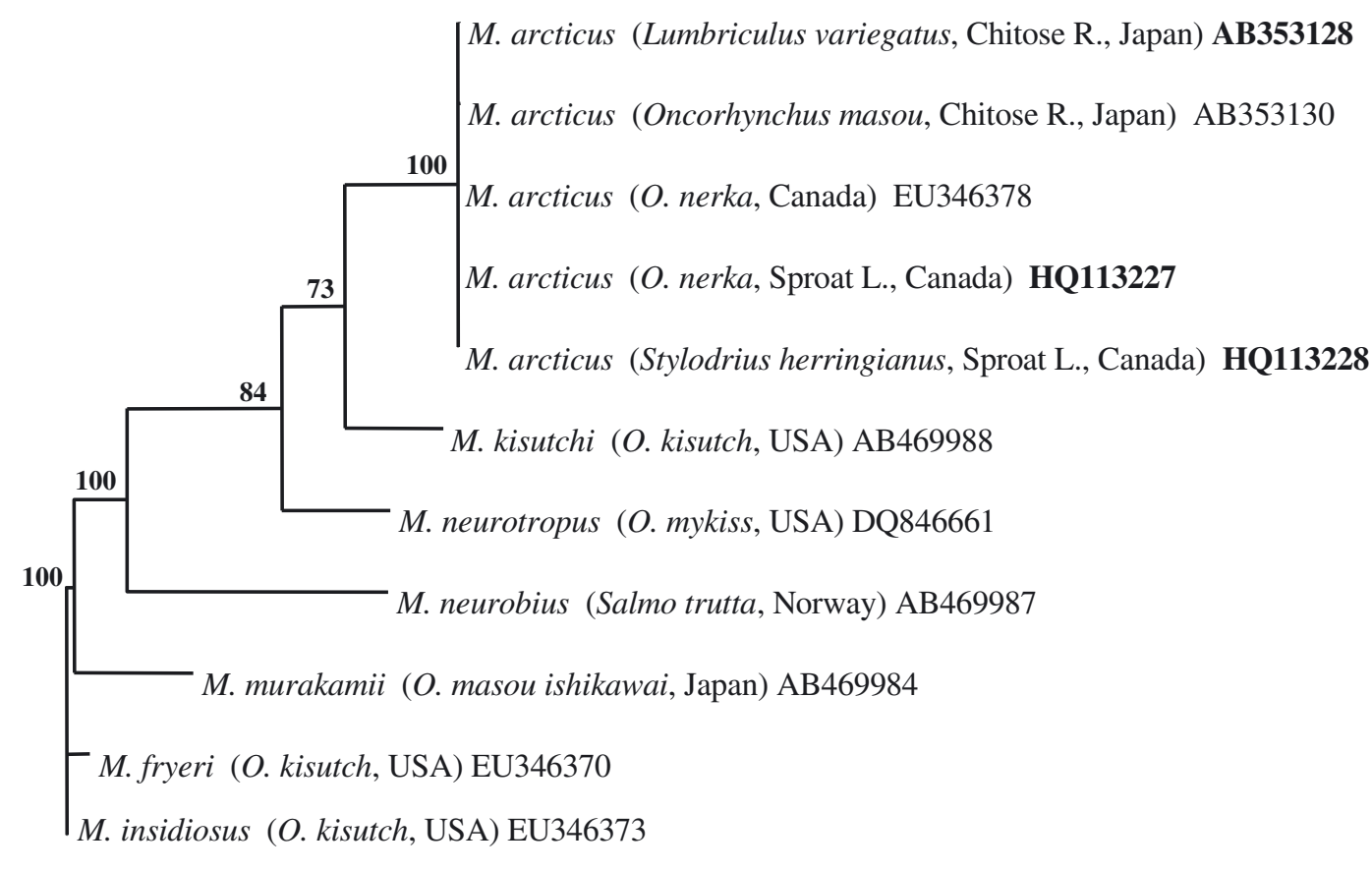

10 changes -

Fig. 2. Myxobolus spp. Maximum parsimony phylogram based on small subunit rDNA sequences of Myxobolus spp. infecting oligochaetes and salmonid nervous tissues. Host, location and GenBank accession numbers also shown. Bootstrap values shown at the nodes are based on 1000 resamplings. The tree is rooted with $M$. insidiosus, a related myxosporean infecting salmonid muscle. The number of nucleotide changes is represented by the scale bar. GenBank accession numbers obtained in the present study are shown in bold 
Table 3. Myxobolus arcticus. Reactivity of Japanese actinospores to the skin mucus of salmonids

\begin{tabular}{|lcc|}
\hline Fish & $\begin{array}{c}\text { No. actinospores } \\
\text { releasing sporoplasms/ } \\
\text { no. examined }\end{array}$ & $\begin{array}{c}\text { Reactivity } \\
(\%)\end{array}$ \\
\hline Masu salmon & $89 / 153$ & 58.2 \\
Chum salmon & $55 / 187$ & 29.4 \\
Pink salmon & $160 / 211$ & 75.8 \\
Sockeye salmon & $94 / 189$ & 49.7 \\
Rainbow trout & $62 / 154$ & 40.3 \\
Brown trout & $57 / 177$ & 32.2 \\
Control & $7 / 187$ & 3.7 \\
\hline
\end{tabular}

no gaps present between the 2 sequences and just 2 nucleotide base changes over the entire region of $2754 \mathrm{bp}$, which includes both ITS regions.

\section{Response of actinospores to skin mucus from different fish species}

Sporoplasm release from Myxobolus arcticus actinospores occurred by exposure to skin mucus from all salmonids examined in this study (Table 3). The proportion of spores that were released varied widely among fish species (29.4-75.8\%) and was significantly higher when compared to unexposed controls $(3.7 \%)$.

\section{Host susceptibility}

Masu and amago salmon were found to be highly susceptible to actinospores of Myxobolus arcticus from Lumbriculus variegatus in Japan (Table 4). All masu salmon fry were infected with $M$. arcticus myxospores 3 mo after exposure to actinospores at a concentration of 100 to 1000 spores fish $^{-1}$. Of 15 masu salmon fry exposed at a concentration of 10 actinospores fish $^{-1}, 7(47 \%)$ were infected. With the exception of 1 out of 24 chum salmon that were exposed, spore formation did not occur in other salmonid species (pink salmon, sockeye salmon, rainbow trout, and brown trout; Table 4). No infection with $M$. arcticus was found in unexposed control fish.

\section{DISCUSSION}

Our transmission experiments demonstrated that Japanese actinospores of Myxobolus arcticus isolated from Lumbriculus variegatus are highly infectious to masu and amago salmon, but not to other salmonid species including sockeye salmon. Masu and amago salmon occur only in Far East Asia (Kato 1990) and share a close phylogenetic relationship (McKay et al. 1996). Even a concentration of 10 actinospores fish ${ }^{-1}$ resulted in recoverable myxospores of M. arcticus from 7 of 15 masu salmon fry. In addition, all stages of masu salmon, from alevin to smolt stages, were susceptible to infection with $M$. arcticus (S. Urawa unpubl. data). These results indicate the high susceptibility of masu salmon to Japanese actinospores of $M$. arcticus.

The lack of infectivity of sockeye salmon to Japanese Myxobolus arcticus is in marked contrast to the Canadian situation, where sockeye salmon are the typical host (Bailey \& Margolis 1987, Kent et al. 1993, McDonald \& Margolis 1995). Kent et al. (1993) reported that 13 of 15 sockeye salmon fry were infected with $M$. arcticus spores after experimental exposure to Canadian actinospores from Stylodrilus heringianus at a concentration of 33 spores fish s $^{-1}$ (Table 4).

Table 4. Myxobolus arcticus. Prevalence in juvenile salmonids exposed to actinospores in Japan and Canada for $1 \mathrm{~h}$

\begin{tabular}{|c|c|c|c|c|}
\hline Fish & $\begin{array}{l}\text { Mean weight } \\
\text { (g) of test fish }\end{array}$ & $\begin{array}{l}\text { No. actino- } \\
\text { spores fish }^{-1}\end{array}$ & $\begin{array}{l}\text { No. fish in- } \\
\text { fected/tested }\end{array}$ & $\begin{array}{c}\text { Prevalence } \\
(\%)\end{array}$ \\
\hline \multicolumn{5}{|c|}{ Exposed to actinospores from Lumbriculus variegatus in Japan } \\
\hline \multirow[t]{6}{*}{ Masu salmon } & 1.32 & 1000 & $15 / 15$ & 100 \\
\hline & 1.34 & 500 & $10 / 10$ & 100 \\
\hline & 1.43 & 200 & $16 / 16$ & 100 \\
\hline & 1.50 & 100 & $14 / 14$ & 100 \\
\hline & 1.41 & 10 & $7 / 15$ & 46.7 \\
\hline & 1.40 & 0 & $0 / 10$ & 0 \\
\hline \multirow[t]{2}{*}{ Amago salmon } & 0.20 & 1000 & $10 / 10$ & 100 \\
\hline & 0.20 & 0 & $0 / 10$ & 0 \\
\hline \multirow[t]{3}{*}{ Chum salmon } & 0.49 & 500 & $0 / 19$ & 0 \\
\hline & 0.70 & 200 & $1 / 5$ & 25.0 \\
\hline & 0.70 & 0 & $0 / 9$ & 0 \\
\hline \multirow[t]{2}{*}{ Sockeye salmon } & 0.55 & 900 & $0 / 15$ & 0 \\
\hline & 0.10 & 500 & $0 / 10$ & 0 \\
\hline \multirow{2}{*}{ Pink salmon } & 0.20 & 500 & $0 / 10$ & 0 \\
\hline & 0.20 & 500 & $0 / 10$ & 0 \\
\hline \multirow[t]{2}{*}{ Rainbow trout } & 0.10 & 500 & $0 / 10$ & 0 \\
\hline & 0.20 & 500 & $0 / 26$ & 0 \\
\hline Brown trout & 19.25 & 1000 & $0 / 12$ & 0 \\
\hline \multicolumn{5}{|c|}{ Exposed to actinospores from Stylodrilus heringianus in Canada ${ }^{a}$} \\
\hline \multicolumn{2}{|c|}{ Sockeye salmon Unknown } & 33 & $13 / 15$ & 86.6 \\
\hline & Unknown & 0 & $0 / 30$ & 0 \\
\hline
\end{tabular}


The positive reactions of actinospores to skin mucus from various salmonid fishes may appear to be contradictory to the results of the transmission experiment, which demonstrated the high host specificity of Myxobolus arcticus. However, the penetration of infectious cells of actinospores into the fish host does not always result in the establishment of infection. It is probable that infectious cells are eliminated by host defense mechanisms or fail to develop into mature myxospores after initial penetration (Yokoyama et al. 2006). Nonspecific responses of actinospores to skin mucus have been reported by many researchers (Yokoyama et al. 1993, Xiao \& Desser 2000, Özer \& Wootten 2002, Kallert et al. 2005), whereas a specific reaction of Thelohanellus hovorkai actinospores to the skin mucus from the natural host (Cyprinus carpio) has also been suggested (Yokoyama et al. 2006). These differences may reflect the diversity of the host-parasite relationship among myxosporeans.

Two Myxobolus arcticus isolates utilize different oligochaete species (Lumbriculus variegatus in Japan and Stylodrilus heringianus in Canada) as the invertebrate host, although both oligochaetes belong to the same family, Lumbriculidae. Thus far, multiple species of oligochaete hosts have been recorded for only 4 myxosporean species: $M$. hungaricus (ElMansy \& Molnár 1997), M. pseudodispar (Székely et al. 1999), Sphaerospora dykovae (as S. renicola, Molnár et al. 1999), and S. truttae (Özer \& Wootten 2000). The former 3 cases were only found by experimental infections, and $S$. truttae had 2 oligochaete hosts (L. variegatus and occasionally Tubifex tubifex) which cohabited in a farm pond. On the other hand, $M$. cerebralis is specific to one species of oligochaete (T. tubifex) despite its wide distribution in the northern hemisphere, and the susceptibility is variable among strains or genotypes of T. tubifex (Stevens et al. 2001, Beauchamp et al. 2002).

Actinospore dimension and host susceptibility are different between the Canadian and Japanese isolates examined here, suggestive of distinct biological entities. Yet comparisons of the rRNA gene sequences showed a high similarity of over $99.9 \%$, suggesting a strong taxonomic affinity of these isolates. Variation in actinospore morphology within a species has been also observed elsewhere (Hallett et al. 2002), suggesting considerable diversity of actinospore morphology even within a species. Sequence similarity is high, but more recent speciation events may not be reflected by fixed genetic changes in such a conserved area of the genome. The differences in host specificity are compelling evidence for distinct species or at least strains of the parasite. Most notably, the isolate from Japan did not experimentally infect a type host, sockeye salmon (Table 4). In spite of these biological data, we hesitate to assign a new species at this time because no material is available for comparison from the type locality. As such, either entity presented here, or possibly neither, is attributable to the original Myxobolus arcticus described from the Russian Far East (Pugachev \& Khokhlov 1979). The combination of this fact and the high similarity of DNA sequence data allows us to reasonably conclude for the time being that both should be considered $M$. arcticus, but minimally these are unique strains.

Actinospore morphology may be a function of the environment. For example, actinospores of parasites infecting bottom-dwelling fish have short caudal processes, whereas those infecting fish drifting in surface water have larger caudal processes (Longshaw $\&$ Feist 2005). We found that Canadian actinospores of Myxobolus arcticus have apparently longer projections than Japanese ones. This morphometric variation might occur after major shift of host selection, and may be caused by environmental differences in each region. In Canada, the oligochaete (Stylodrilus heringianus) and fish (sockeye salmon) hosts are distributed in a lake, where the long projections may increase the buoyancy of the actinospores and therefore increase the opportunity to lead to infections in fish. In Japan, however, the oligochaete (Lumbriculus variegatus) and fish (masu salmon) hosts inhabit a steep stream, where actinospores with long projections may be rapidly swept downstream, resulting in few chances to encounter a salmonid host. Further field and laboratory experiments will be required to test this hypothesis.

Patterns of parasite prevalence and protein polymorphisms have indicated that both sockeye and masu salmon have extremely high precision of homing migration for spawning (Awakura et al. 1982, Okazaki 1986, Quinn et al. 1987). This implies that the geographical segregation of anadromous salmonid hosts provided an opportunity for the onset of divergent evolution of the parasite. In conclusion, we presume that Myxobolus arcticus specialized its host selection and actinospore morphology for its local environments in the ongoing process of differentiation, potentially leading to speciation.

Acknowledgements. We thank A. Ohtaka of Hirosaki University for identification of the oligochaetes. We also thank K. Hyatt of the Pacific Biological Station for providing sockeye salmon samples. We are grateful to an anonymous 
reviewer for significantly improving the manuscript. This study was supported by the Fisheries Research Agency, while molecular analysis were conducted in Malaysia and supported by a University of Malaya HIR grant no. UMC/ 625/1/HIR/027.

\section{LITERATURE CITED}

Awakura T, Kojima H, Sugiwaka K, Ogawa T (1982) Studies of parasites of masu salmon Oncorhynchus masou-III; Myxobolus (Protozoa: Myxosporea) found in spinal cord. Sci Rep Hokkaido Fish Hatchery 37:37-47 (in Japanese)

Awakura T, Nagasawa K, Urawa S (1995) Occurrence of Myxobolus arcticus and M. neurobius (Myxozoa: Myxosporea) in masu salmon Oncorhynchus masou from northern Japan. Sci Rep Hokkaido Salmon Hatch 49: 35-40

Bailey RE, Margolis L (1987) Comparison of parasite fauna of juvenile sockeye salmon (Oncorhynchus nerka) from southern British Columbian and Washington State lakes. Can J Zool 65:420-431

Bartošová P, Fiala I, Hypša V (2009) Concatenated SSU and LSU rDNA data confirm the main evolutionary trends within myxosporeans (Myxozoa: Myxosporea) and provide an effective tool for their molecular phylogenetics. Mol Phylogenet Evol 53:81-93

> Beauchamp KA, Gay M, Kelly GO, El-Matbouli M, Kathman RD, Nehring RB, Hedrick RP (2002) Prevalence and susceptibility of infection to Myxobolus cerebralis, and genetic differences among populations of Tubifex tubifex. Dis Aquat Org 51:113-121

> Canning EU, Okamura B (2004) Biodiversity and evolution of the Myxozoa. Adv Parasitol 56:43-131

> Diamant A (1997) Fish-to-fish transmission of a marine myxosporean. Dis Aquat Org 30:99-105

El-Mansy A, Molnár K (1997) Development of Myxobolus hungaricus (Myxosporea: Myxobolidae) in oligochaete alternate hosts. Dis Aquat Org 31:227-232

Ferguson JA, Atkinson SD, Whipps CM, Kent ML (2008) Molecular and morphological analysis of Myxobolus spp. of salmonid fishes with the description of new species. J Parasitol 94:1322-1334

Fiala I (2006) The phylogeny of Myxosporea (Myxozoa) based on small subunit ribosomal RNA gene analysis. Int J Parasitol 36:1521-1534

Freeman MA, Yokoyama H, Ogawa K (2008) PCR primer suite for DNA sequencing of myxozoan small subunit rDNA, with descriptions of two new species from the Japanese anglerfish, Ceratomyxa anko n. sp. and Zschokkella lophii n. sp. J Fish Dis 31:921-930

Hall TA (1999) BioEdit: a user-friendly biological sequence alignment editor and analysis program for Windows 95/98/ NT. Nucleic Acids Symp Ser 41:95-98

- Hallett SL, Atkinson SD, El-Matbouli M (2002) Molecular characterisation of two aurantiactinomyxon (Myxozoa) phenotypes reveals one genotype. J Fish Dis 25:627-631

Kallert DM, El-Matbouli M, Hass W (2005) Polar filament discharge of Myxobolus cerebralis actinospores is triggered by combined non-specific mechanical and chemical cues. Parasitology 131:609-616

Kato F (1990) Life histories of masu and amago salmon (Oncorhynchus masou and Oncorhynchus rhodurus). In: Groot C, Margolis L (eds) Pacific salmon life histories. UBC Press, Vancouver, p 447-520
Kent ML, Whitaker DJ, Margolis L (1993) Transmission of Myxobolus arcticus Pugachev and Khokhlov, 1979, a myxosporean parasite of Pacific salmon, via a triactinomyxon from the aquatic oligochaete Stylodrilus heringianus (Lumbriculidae). Can J Zool 71:1207-1211

Kent ML, Andree KB, Bartholomew JL, El-Matbouli M and others (2001) Recent advances in our knowledge of the Myxozoa. J Eukaryot Microbiol 48:395-413

> Lom J, Arthur JR (1989) A guideline for preparation of species descriptions in Myxosporea. J Fish Dis 12:151-156

Lom J, Dyková I (2006) Myxozoan genera: definition and notes on taxonomy, life-cycle terminology and pathogenic species. Folia Parasitol (Praha) 53:1-36

Lom J, McGeorge J, Feist SW, Morris D, Adams A (1997) Guidelines for the uniform characterisation of the actinosporean stages of parasites of the phylum Myxozoa. Dis Aquat Org 30:1-9

Longshaw M, Feist SW (2005) The role of morphology and ecology in the transmission of actinospore types (Myxozoa) in freshwater ecosystems. EAFP 12th Int Conf, Copenhagen, p 195 (Abstract)

Margolis L (1998) Are naturally-occurring parasite 'tags' stable? An appraisal from four case histories involving Pacific salmonids. North Pac Anadromous Fish Comm Bull 1:205-212

McDonald TE, Margolis L (1995) Synopsis of the parasites of fishes of Canada: supplement (1978-1993). Can Spec Publ Fish Aquat Sci 122:1-265

McKay SJ, Devlin RH, Smith MJ (1996) Phylogeny of Pacific salmon and trout based on growth hormone type-2 and mitochondrial NADH dehydrogenase subunit 3 DNA sequences. Can J Fish Aquat Sci 53:1165-1176

Moles A, Heifetz J (1998) Effects of the brain parasite Myxobolus arcticus on sockeye salmon. J Fish Biol 52: 146-151

Moles A, Jensen K (2000) Prevalence of the sockeye salmon brain parasite Myxobolus arcticus in selected Alaska streams. Alsk Fish Res Bull 6:85-93

Moles A, Rounds P, Kondzela C (1990) Use of the brain parasite Myxobolus neurobius in separating mixed stocks of sockeye salmon. Am Fish Soc Symp 7:224-231

Molnár K, El-Mansy A, Székely C, Baska F (1999) Experimental identification of the actinosporean stage of Sphaerospora renicola Dykova \& Lom 1982 (Myxosporea: Sphaerosporidae) in oligochaete alternate hosts. J Fish Dis 22:143-153

Okazaki T (1986) Genetic variation and population structure in masu salmon Oncorhynchus masou of Japan. Bull Jpn Soc Sci Fish 52:1365-1376

Özer A, Wootten R (2000) The life cycle of Sphaerospora truttae (Myxozoa: Myxosporea) and some features of the biology of both the actinosporean and myxosporean stages. Dis Aquat Org 40:33-39

Özer A, Wootten R (2002) Biological characteristics of some actinosporeans. J Nat Hist 36:2199-2209

Pugachev ON, Khokhlov PP (1979) Myxosporeans of the genus Myxobolus-parasites of the brain and spinal cord of Salmonidae. In: Systematics and ecology of fishes in the Far East. Academy of Sciences Press, Vladivostok, p 137-139 (in Russian)

> Quinn TP, Wood CC, Margolis L, Riddell BE, Hyatt KD (1987) Homing in wild sockeye salmon (Oncorhynchus nerka) populations as inferred from differences in parasite prevalence and allozyme allele frequencies. Can J Fish Aquat Sci 44:1963-1971 
Saitou N, Nei M (1987) The neighbor-joining method: a new method for reconstructing phylogenetic trees. Mol Biol Evol 4:406-425

Stevens R, Kerans BL, Lemmon JC, Rasmussen C (2001) The effects of Myxobolus cerebralis myxospore dose on triactinomyxon production and biology of Tubifex tubifex from two geographic regions. J Parasitol 87:315-321

Swofford DL (2002) PAUP* phylogenetic analysis using parsimony (*and other methods), v. 4.0 beta10. Sinauer Associates, Sunderland, MA

Székely C, Molnár K, Eszterbauer E, Baska F (1999) Experimental detection of the actinospores of Myxobolus pseudodispar (Myxosporea: Myxobolidae) in oligochaete alternate hosts. Dis Aquat Org 38:219-224

Thompson JD, Gibson TJ, Plewniak F, Jeanmougin F, Higgins DG (1997) The CLUSTAL-X windows interface: flexible strategies for multiple sequence alignment aided by quality analysis tools. Nucleic Acids Res 25: 4876-4882

Urawa S, Awakura T (1994) Protozoan diseases of freshwater fishes in Hokkaido. Sci Rep Hokkaido Fish Hatch 48: 47-58

Urawa S, Nagasawa K, Margolis L, Moles A (1998) Stock identification of chinook salmon (Oncorhynchus tshawytscha) in the North Pacific Ocean and Bering Sea by parasite tags. North Pac Anadromous Fish Comm Bull 1: 199-204

Urawa S, Iida Y, Freeman MA, Yanagida T, Karlsbakk E, Yokoyama H (2009) Morphological and molecular comparisons of Myxobolus spp. in the nerve tissues of salmonid fishes with the description of Myxobolus mura-

Editorial responsibility: David Marcogliese,

Montreal, Quebec, Canada kamii n. sp., the causative agent of myxosporean sleeping disease. Fish Pathol 44:72-80

Van der Auwera G, Chapelle S, De Wachter R (1994) Structure of the large ribosomal subunit RNA of Phytophthora megasperma, and phylogeny of the oomycetes. FEBS Lett 338:133-136

> Whipps CM, Kent ML (2006) Phylogeography of the cosmopolitan marine parasite Kudoa thyrsites (Myxozoa: Myxosporea). J Eukaryot Microbiol 53:364-373

> Xiao C, Desser SS (2000) The longevity of actinosporean spores from oligochaetes of Lake Sasajewun, Algonquin Park, Ontario, and their reaction to fish mucus. J Parasitol 86:193-195

> Yokoyama H (2003) A review: gaps in our knowledge on myxozoan parasites of fishes. Fish Pathol 38:125-136

Yokoyama H, Urawa S (1997) Fluorescent labelling of actinospores for determining the portals of entry into fish. Dis Aquat Org 30:165-169

Yokoyama H, Ogawa K, Wakabayashi H (1991) A new collection method of actinosporeans - a probable infective stage of myxosporeans to fishes - from tubificids and experimental infection of goldfish with the actinosporean, Raabeia sp. Fish Pathol 26:133-138

Yokoyama H, Ogawa K, Wakabayashi H (1993) Some biological characteristics of actinosporeans from the oligochaete Branchiura sowerbyi. Dis Aquat Org 17: 223-228

Yokoyama H, Kim JH, Urawa S (2006) Differences in host selection of actinospores of two myxosporeans, Myxobolus arcticus and Thelohanellus hovorkai. J Parasitol 92: 725-729

Submitted: October 25, 2010; Accepted: July 19, 2011 Proofs received from author(s): September 21, 2011 